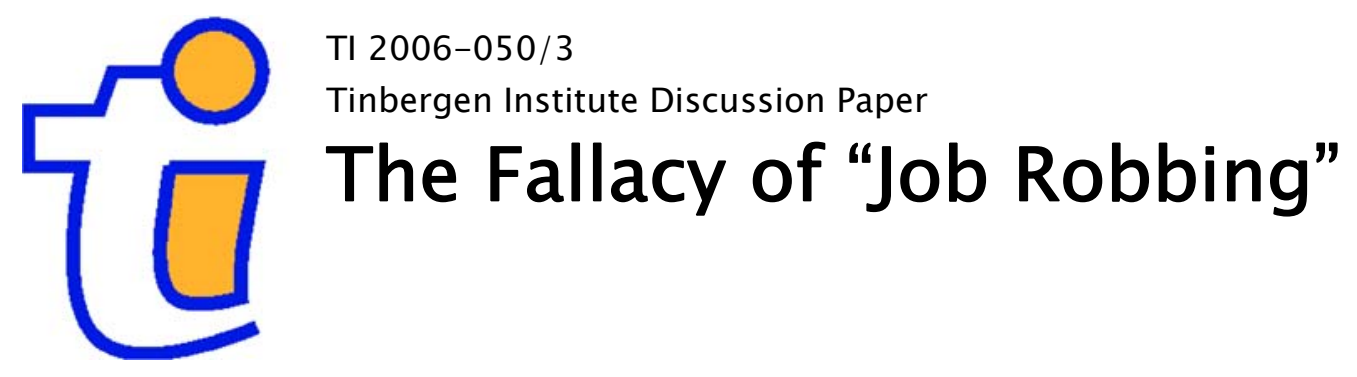

Simonetta Longhil

Peter Nijkamp?

Jacques Poot ${ }^{3}$

1 University of Essex, UK;

2 Free University Amsterdam, and Tinbergen Institute, The Netherlands;

3 University of Waikato, New Zealand. 


\section{Tinbergen Institute}

The Tinbergen Institute is the institute for economic research of the Erasmus Universiteit Rotterdam, Universiteit van Amsterdam, and Vrije Universiteit Amsterdam.

Tinbergen Institute Amsterdam

Roetersstraat 31

1018 WB Amsterdam

The Netherlands

Tel.: $\quad+31(0) 205513500$

Fax: $\quad+31(0) 205513555$

Tinbergen Institute Rotterdam

Burg. Oudlaan 50

3062 PA Rotterdam

The Netherlands

Tel.: $\quad+31(0) 104088900$

Fax: $\quad+31(0) 104089031$

Please send questions and/or remarks of nonscientific nature to driessen@tinbergen.nl.

Most TI discussion papers can be downloaded at http://www.tinbergen.nl. 


\title{
The Fallacy of "Job Robbing": A Meta-Analysis of Estimates of the Effect of Immigration on Employment
}

\author{
Simonetta Longhi ${ }^{1}$, Peter Nijkamp ${ }^{2}$, Jacques Poot $^{3}$ \\ 1 Institute for Social and Economic Research, University of Essex, Colchester, UK (e-mail: \\ slonghi@essex.ac.uk) \\ 2 Dept. of Spatial Economics, Free University, Amsterdam, The Netherlands (e-mail: \\ pnijkamp@feweb.vu.nl) \\ Population Studies Centre, University of Waikato, Hamilton, New Zealand (e-mail: \\ jpoot@waikato.ac.nz)
}

\begin{abstract}
Immigration is a phenomenon of growing significance in many countries. Increasing social tensions are leading to political pressure to limit a further influx of foreign-born persons on the grounds that the absorption capacity of host countries has been exceeded and social cohesion threatened. There is also in public discourse a common perception of immigration resulting in economic costs, particularly with respect to wages and employment opportunities of the native born. This warrants a scientific assessment, using comparative applied research, of the empirical validity of the perception of a negative impact of immigration on labour market outcomes. Applying meta-analytic techniques to 165 estimates from 9 recent studies for various OECD countries, we assess in this paper whether immigration leads to job displacement among native workers. The 'consensus estimate' of the decline in native-born employment following a 1 percent increase in the number of immigrants is a mere 0.024 percent. However, the impact is somewhat larger on female than on male employment. The negative employment effect is also greater in Europe than in the United States. Furthermore, the results are sensitive to the choice of the study design. For example, failure to control for endogeneity of immigration itself leads to an underestimate of its employment impact.
\end{abstract}

JEL classification: $F 22$, J61

Key words: Immigration, Employment, Meta-Analysis

PN216SLJP 


\section{Introduction}

The world is witnessing an unprecedented increase in flows of people across borders for business, pleasure, education, or to seek greater wellbeing in a foreign land. Global economic integration, the declining real costs of communication and transportation, persisting gaps in the standard of living between rich and poor nations and the continued vulnerability of the latter to manmade and natural calamities are all contributing to a notable increase in the foreign-born population and growing ethnic diversity in many nations.

The study of international migration had been guided for a long-time by the traditional paradigm of the new settler and his family who made a once in a lifetime move to a distant land, usually to the 'New World'. There is no dispute that this migration was a rational choice to the benefit of the migrant, but there was also a broad consensus that this international reallocation of labour was to the benefit of both sending and receiving countries, except perhaps for the negative externalities associated with a brain drain from developing countries (e.g., Bhagwati, 1976).

As migrants are now an increasing proportion of the population in many countries, and as migration flows are becoming more complex with temporary, return and repeat migrations becoming commonplace, the need for careful scientific study of the socioeconomic impact of immigration across a wide range of countries and immigrant types is great. Many studies have already been undertaken and have been extensively surveyed, see for example Gorter et al. (1998), Borjas (1999) and Dustmann and Glitz (2005).

While there are many aspects to the impact of immigration, including effects on inflation, housing, social cohesion, the environment, etc. (see e.g. Poot and Cochrane, 2005, for a review in the New Zealand context), central to public discourse on immigration is the impact on the labour market and specifically the public perception that migrants might 'rob jobs' of the native-born and might bid down wages. There are at least some fifty studies that have been published during the last quarter century that test either or both of these assertions using a wide range of techniques and data sets. These studies have led to a - to the layperson at least bewildering array of results.

This is not surprising given the complexity of the labour market and the wide range of potential responses of workers and firms following an influx of immigrants. 
We may expect an increase in local demand (particularly in the non-traded sector), the possible greater use of labour-intensive techniques or greater specialisation in labour intensive outputs, a downward push on wages for those who directly compete with immigrants and an increase in employment of those with complementing skills, changing labour force participation and migration decisions among the native born, etc. The measured outcome in each empirical study is not just sensitive to the chosen methodology but also to the relative strength of these various adjustment mechanisms. In addition, the short-run impact may be quite different from the long-run impact.

One way to carry out a cross-country comparative study of the empirical results is to simply tabulate authors, country, methodology, type of impact and results, such as done competently for the labour market impact by Okkerse (2005). The problem, however, with a narrative discussion of such a table is that it may not readily pick up important associations between particular study features and the results.

An alternative approach that is less subjective and also has the potential to enhance the statistical efficiency of estimation of parameters of interest, is metaanalysis. The meta-analytic approach to research synthesis has a long tradition in the experimental sciences (Cooper and Hedges, 1994) but has also been growing in popularity in economics, as is evident for example from a 2005 special issue of the Journal of Economic Surveys (Roberts, 2005). In a previous paper, published in that special issue we applied meta-analytic techniques to empirical results from a set of 18 papers on the impact of immigration on wages of the native born (Longhi et al. 2005). These papers altogether generated 348 estimates of the percentage change in the wage of a native worker with respect to a 1 percentage point increase in the ratio of immigrants over native workers. The focus on the wage impact was deliberate: there are simply many more estimates of the impact of immigration on wages than estimates of the impact on employment or unemployment outcomes. A larger dataset increases the statistical power of tests of the relevance of specific study features for the empirical results, and the selection of wage effects for meta-analysis was therefore a natural choice.

The difference in the number of available empirical estimates of wage and employment outcomes is related to the development of research on this topic. The earlier studies were primarily done for the United States, which has a relatively flexible labour market in which wage effects are the natural choice of measuring the impact of an exogenous supply shock through immigration on specific labour markets 
(geographically defined, or by skill). European research initially replicated the US studies, but given the persistently high unemployment rates in several European countries, European studies give greater recognition of disequilibrium in the labour market, and take into account that wages may be rather sticky and immigration is therefore more likely to affect employment opportunities of the native born rather than wages.

Given the increasing number of European studies in recent years it has been possible to identify nine studies conducted during the last decade, including three from the US that yielded 165 comparable estimates of the effect of immigration on employment of the native born across a range of countries. In the present paper we carry out a meta-analysis of these 165 estimates. The simple average of these 165 estimates of the decline in native-born employment following a 1 percent increase in the number of immigrants in the local labour market is a mere 0.024 percent. Thus the idea of fixed aggregate employment in a given area, with the native-born handing over their jobs to the new immigrants, is a fallacy. The meta-analysis, however, also provides a range of additional results. For example, the impact is somewhat larger on female than on male native-born employment. The impact on employment effect is also greater in Europe than in the United States, consistent with the lesser flexibility in European labour markets. Furthermore, the results are sensitive to the choice of the study design. For example, failure to control for endogeneity of immigration itself leads to an underestimate of its employment impact. There is also some evidence of publication bias: fewer studies have been published with statistically insignificant results than might have been expected based on replication of the same statistical model across a range of data sets.

The remainder of the paper is organised as follows. The next section explains how the nine studies have been selected. Section 3 provides an overview of relevant study characteristics. Section 4 establishes the associations between study characteristics and study outcomes by means of meta-regression analysis. Section 5 sums up.

\section{The Primary Studies}

The majority of studies estimating the impact of immigration on employment opportunities of natives estimate regressions similar to equation (1) below, using 
regional data. They exploit the fact that immigrants are spatially distributed very differently from the locally-born population, with particularly a high concentration of the former in the metropolitan areas. By focussing on the commonly adopted area approach to measuring the labour market impact of immigration, we do not consider ij the present paper a range of other approaches such as production theory and factor proportions approach, aggregate time series analyses, natural experiments and computable general equilibrium analyses (see Okkerse 2005). A change in local employment is explained - among other variables - in area-based regressions by the share of foreign immigrants in the regional labour market:

$$
\Delta E_{r}\left(t, t^{\prime}\right)=\beta \Delta m_{r}\left(t, t^{\prime}\right)+\mathbf{x}_{\mathbf{r}}{ }^{\prime} \boldsymbol{\alpha}+u_{r}\left(t, t^{\prime}\right)
$$

where $\Delta E_{r}\left(t, t^{\prime}\right)$ is the change between years $t$ and $t^{\prime}$ in employment of natives who live in region $r ; \Delta m_{r}\left(t, t^{\prime}\right)$ is the change in the stock of immigrants in region $r$ over period $t$ to $t^{\prime} ; \mathbf{x}_{\mathrm{r}}$ is a vector of control variables with coefficient vector $\boldsymbol{\alpha}$; and $u_{r}$ is the stochastic error term. The parameter of interest is $\beta$; estimates of $\beta$ vary within and between primary studies. In meta-analysis, estimates of $\beta$ are referred to as effect sizes.

There are many other research designs possible to calculate the effect of immigration on employment. When estimates are based on different metrics, the only means of combining estimates is to focus entirely on measures of strength of association, such as partial correlation coefficients or $t$ statistics. In the immigration debate, however, the issue is not so much the statistical significance of the effect of immigration on employment but rather the magnitude of this effect. By restricting ourselves to estimates of equation (1), we can use information on magnitude as well as statistical significance. The drawback of confining the meta-analysis to the particular empirical approach embodied in (1) is that the number of available studies is much less than would be the case in a meta-analysis of strength of association only.

Even among the nine studies that we have collected that use equation (1), there can be a wide range of estimated effect sizes due to differences in design of the primary studies. For example, the primary studies use data for different countries. They also have different assumptions about the size of the local labour market area and about the substitutability between groups of workers. In addition, most studies 
report a number of model specifications. In Section 4 we model the resulting heterogeneity among effect sizes by means of meta-regression techniques.

Table 1 lists the nine primary studies in our meta-analysis from which we collected 165 estimates of $\beta$, the effect of immigration on employment. ${ }^{1}$

\section{TABLE 1 ABOUT HERE}

Among the 165 estimates, 22 are obtained from primary studies that use the employment level as dependent variable (Winter-Ebmer and Zimmermann, 1998; Dustmann et al., 2005); the remaining 143 estimates are obtained from primary studies in which employment is measured as a percentage of the population (Borjas et al., 1997; Enchautegui, 1997; Pischke and Velling, 1997; Card, 2001; Friedberg, 2001; Angrist and Kugler, 2003; Carrasco et al., 2004).

Heterogeneity is also present in the way the main explanatory variable is defined. Two studies do not rescale the immigrant variable (Enchautegui, 1997; and Friedberg, 2001); two rescale it by the labour force (Winter-Ebmer and Zimmermann, 1998; and Card, 2001); two by the total population (Pischke and Velling, 1997 and Angrist and Kugler, 2003); one by the number of natives (Dustmann et al., 2005); and one by total employment (Carrasco et al., 2004). Borjas et al. (1997) rescale the change in the number of immigrants by the total number of natives.

To turn such heterogeneous estimates into comparable measures of the impact of immigration on employment, we converted the effect sizes into elasticities $(\gamma)$ :

$$
\gamma=\frac{\partial \ln E_{r}(t)}{\partial \ln m_{r}(t)}=\frac{\partial E_{r}(t)}{\partial m_{r}(t)} \times \frac{m_{r}(t)}{E_{r}(t)}
$$

The corresponding standard error is recovered in a way that ensures that the $t$-values are exactly the same before and after the transformation, such that the transformation does not affect the significance level of the compared effect sizes. The elasticity of local employment of the native born with respect to changes in the immigrants' share of employment, $\gamma$, is therefore the dependent variable in our meta-regressions.

\footnotetext{
${ }^{1}$ To avoid biased results due to the influence of implausible outliers, one estimate among the 34 collected from the study by Carrasco et al. (2004) was omitted.
} 
Figure 1 shows the distribution of the elasticities, which is clearly not normal, and seems slightly skewed. The majority of effect sizes are concentrated close to zero and have small negative values. The figure also shows a small number of relatively large positive effect sizes. Because of the heterogeneity of the primary studies, such positive values might be due to specific characteristics of the primary studies. This will be investigated in the following section by means of meta-analytic techniques.

\section{FIGURE 1 ABOUT HERE}

\section{Study Characteristics}

Among the 165 elasticities extracted from the nine studies listed in Table 1, 48 were computed using US data, while 117 were computed using data for European countries and Israel. A previously undertaken meta-analysis of the effect of immigration on wages (Longhi et al., 2005) suggested that immigration has a bigger impact on EU countries than on the US, and that this result might be attributed to the lower mobility of EU - compared to US - workers. The higher internal worker mobility in the US might make the identification of the impact of immigration more difficult when US data are used, and might therefore lead to an underestimation of the effect of immigration on local wages. If wages in the EU are less flexible than wages in the US, immigration might be expected to have a more noticeable employment effect in the EU than in the US. The first study characteristic that we investigate here is therefore concerned with the data used by the primary studies. We distinguish between elasticities computed using data for the US, from those that were computed using EU - or Israeli - data.

Table 2 shows descriptive statistics of the 165 elasticities, computed for the total sample and separately for each of a range of study characteristics. The first row of Table 2 shows the (unweighted) average, standard deviation, minimum and maximum value of the full set of effect sizes included in the analysis. In our dataset the elasticity of local employment to immigration ranges from a minimum of -0.390 to a maximum of 0.620 , with an unweighted mean of -0.024 . Thus, based on the simple average, we could conclude that a 1 percent increase in immigration lowers local native employment by only $0.024 \%$.

\section{TABLE 2 ABOUT HERE}


We see from Table 2 also that the average effect size in the US (-0.005) is rather smaller in absolute terms than in other countries (-0.032), which is consistent with the notion that the employment effect is greater in rather less flexible labour markets.

In an open labour market, adjustment processes such as native out-migration, trade and capital inflow might bias the estimation of the effect of immigration towards zero. Since the effect of these adjustment processes is expected to be larger in small than in big areas (Card, 2001), those studies focusing on small geographic areas are more likely to miss a negative impact of immigration than those focusing on large areas (Borjas et al., 1997). For example, Borjas (2005) finds a higher impact of immigration on wages when estimated at the national level, and that native's migration accounts for 40-60 percent of the difference between the estimates at state level and the estimates at the level of the metropolitan areas. Table 2 shows an average effect size of -0.006 for small areas and -0.033 for bigger areas.

In a similar way, different definitions of the labour market might be connected to different estimates of the impact of immigration on employment. While some studies (Enchautegui, 1997; Pischke and Velling, 1997; Winter-Ebmer and Zimmermann, 1998; Friedberg, 2001; Angrist and Kugler, 2003; and Dustmann et al., 2005) define the local labour market only in terms of geographical areas or industries, others define it in terms of both geography and occupations/skills (Card, 2001; and Borjas et al., 1997). Since a narrower definition might yield a better identification of workers that are close substitutes to each other, we expect the studies that use a combination of geography and occupations/skills to lead to estimated impacts of immigration that are greater than studies that use broader definitions of local labour markets. Based on simple average effect sizes, this is indeed the case in Table 2.

Since the female labour force participation rate has been found to react more to changes in wages and unemployment rates than the male labour force participation rate (see, e.g., Borjas, 1996), those primary studies focusing only on the male labour force might underestimate the impact of immigration on employment. Furthermore, it has been suggested (Borjas, 2003) that immigrants are likely to be substitutes for lowskilled natives and for females, and complements to highly skilled natives. Moreover, because of certain characteristics, such as language skills, education obtained in the home country and culture, immigrants might have only a small impact on natives, but a bigger impact on earlier immigrants. On the other hand, if immigrants depress 
wages of earlier immigrants but not wages of natives (see, e.g. Longhi et al., 2005), then they might have a bigger employment effect on natives than immigrants.

By and large, the differences among study designs discussed above are borne out by the simple averages in Table 2 . In absolute terms, the effect on employment is larger for women than for men, larger for low skilled workers than for workers generally, and larger for earlier immigrants than for natives.

Immigrants tend to become more similar to natives the longer the time spent in the host country. Earlier immigrants might be closer substitutes to natives than recent immigrants are. As a result, those primary studies focusing on the impact of recent immigrants are more likely to give a clearer picture of the impact of immigration.

Specific characteristics of the estimation techniques used by each primary study may have a relevant impact on the estimated effect of immigration. Friedberg and Hunt (1995) argue that factor price equalisation might cause an underestimation of the effect of immigration computed on cross-section data; Altonji and Card (1991) suggest the use of first-differences to capture the short-run effects of immigration. First-differenced data are probably less affected by city-specific unobserved characteristics that might influence immigrant density and/or natives' outcomes.

Another source of underestimation of the effects of immigration might be the non-random distribution of immigrants across labour market areas. If immigrants locate in areas with higher employment, instrumental variables are needed to correct for endogeneity and to avoid the estimation of a spurious relationship between employment and immigration (see Friedberg and Hunt, 1995; Borjas, 1999; and Card, 2001). On the other hand, if immigrants tend to cluster where other immigrants of the same type are already located, as suggested by Altonji and Card (1991), immigrants' location might depend more on historical than on economic reasons, and instruments might not be needed. A set of dummies for the estimation techniques used in the primary studies will shed light on the impact of the study design on the estimated impact of immigration. The study characteristics 'Data', 'Weights', and 'Instruments' (see Table 2) are used to analyse the impact of different estimation techniques on the estimated employment effect of immigration. Some of these characteristics might be associated with the 'quality' of each effect size and primary study.

The means of the effect sizes reported in Table 2 are plotted in Figures 2, 3 and 4 separately by study characteristic. The dots are the mean effect sizes of each possible choice for each of the study characteristic listed on the horizontal axes. The 
horizontal line is the overall average mean of -0.024. For the sake of comparability, in all three figures the first group of means refers to the average effect size for each of the primary studies. The two primary studies with the highest (positive) mean effect sizes are Enchautegui (1997) and Friedberg (2001), while the two studies with the lowest (negative) mean effect sizes are Card (2001) and Angrist and Kugler (2003).

\section{FIGURE 2 ABOUT HERE}

FIGURE 3 ABOUT HERE

FIGURE 4 ABOUT HERE

Figure 2 shows that the average effect size is slightly above the mean when computed for natives, while it is lower than the mean when computed on earlier immigrants. The average effect size for low-skilled workers is more negative than for all workers. Furthermore, immigration seems to have a bigger negative impact when computed using data for female workers than for male workers. Those primary studies that do not distinguish between the two genders generate an average estimate of the impact of immigration on native employment that is positive. The fact that the average elasticity computed by those studies that do not distinguish between genders is not found to fall in between the average elasticity for men and the average elasticity for women highlights a weakness of this type of bivariate analysis. Other specific study characteristics may have a combined effect with the gender variable, and might therefore be responsible for the counterintuitive result. Such problems can easily be solved by means of multivariate meta-regression techniques. This will be done in the next section.

Figure 3 shows that the effect sizes are on average less negative in the US, for smaller regions and where areas are purely geographically defined rather than also in terms of skill group. Figure 4 shows that estimates that remove region-specific effects through first differencing tend to suggest a positive employment impact, while controls for heteroscedasticity by regression weights do not have a noticeable impact on the average effect size. The use of instrumental variables to control for endogeneity in the immigrant share, however, does lead to a more negative average effect size. Nonetheless, as noted above, some of these bivariate effects of study characteristics may not hold up in a multivariate context. We will now investigate this by mean of meta-regression analysis in the next section. 


\section{Meta-Regression Analysis}

In the present section we will report the results of our meta-regression analysis. The study characteristics identified in Table 2 are regressed on the elasticity of employment to immigration, $\gamma$. The results are shown in Table 3.

An important issue is the extent to which our sample of effect sizes may be considered representative of the population of studies undertaken on this topic. Because of the tendency of authors, referees and editors to favour the publication of statistically significant results, the sample of studies - and to a lesser extent the sample of the effect sizes - might be biased toward more significant results (Stanley et al., 2004). This problem might be reduced by including in the analysis both published and unpublished primary studies. Nevertheless, authors might choose the significant results that conform to their theories as their preferred model specification, but nevertheless publish also (some of) their non-significant results. The effect of publication bias can then at least be partially mitigated by sampling all estimates published in each primary study. To reduce the possibility of publication bias, we adopt the technique of multiple sampling by including in our analysis all (or most) effect sizes published by each primary study.

\section{TABLE 3 ABOUT HERE}

It is possible to test for publication bias by assessing the relationship between the effect sizes and their standard errors: if there is no publication bias, a regression of the standard errors on the effect sizes will show an insignificant coefficient. If there is a publication bias, and if significant effect sizes are more likely to be published, the ratios of effect sizes divided by their standard errors will bunch around two (see Card and Krueger, 1995). Like Ashenfelter et al. (1999), we simultaneously correct for heterogeneity of the effect sizes by adding dummies for the other study characteristics to the regression testing for publication bias. The first regression estimates have been computed using OLS, and the results are shown in the first column of Table 3 . $^{2}$

\footnotetext{
${ }^{2}$ All estimations have been carried out with Stata 9.
} 
The coefficient of the standard error is positive and statistically significant, suggesting the presence of publication bias; the coefficients of the remaining explanatory variables should estimate the impact of each study characteristic on the estimated elasticity, ceteris paribus.

A common practice in meta-regression analysis is to weight each effect size by the inverse of its standard error, and then to explain the heterogeneity of the study results by means of a linear regression estimated with Weighted Least Squares (WLS). In our case, however, weighting by the inverse standard errors would result in higher weights given to the statistically significant - and possibly biased - estimated effect sizes. Because of the negative relationship between standard error and sample size, a better choice for weighting each elasticity is the square root of the sample size from which it is estimated. There is no relationship between the standard errors of the estimated effect sizes and the sample sizes from which they are estimated. The correlation between these two variables in our dataset is only -0.0266 . The standard errors of the effect sizes can then continue to be used as an explanatory variable in our meta-regression to correct for publication bias. The results of the WLS regression with weights equal to the square root of the samples sizes are shown in the second column of Table 3 .

Given the small number of effect sizes that could be included in our metaanalysis, it is possible to investigate the impact of only a small set of study characteristics. Such a small number of explanatory variables is unlikely to capture the full heterogeneity of the effect sizes. In such a situation, the mixed-effect model, typically estimated by means of Maximum Likelihood (ML) methods, should be preferred (see, for example, Sutton et al., 2000). Similarly to the WLS case, rather than weighting each effect size by the inverse of its standard error, we weight them by the square root of the sample size. The results of the mixed effect model are shown in the third column of Table 3 .

The three estimation techniques - OLS, WLS and ML - seem to produce rather stable estimates of the impact of each study characteristic on the estimated elasticity of employment. The results in Table 3 suggest that immigration has a bigger negative impact on employment in EU countries and Israel than in the US. Those primary studies focusing on 'Other Countries' tend to estimate elasticities that are between 0.09 and 0.11 more negative than those elasticities estimated by primary studies focusing on the US. The greater detrimental employment effect in European 
labour markets might have several explanations. For example, the lower wage flexibility that characterises EU countries might reduce the wage impact of immigration but consequently increase its effect on employment opportunities of residents. On the other hand, as already mentioned, adjustment effects such as natives' migration are likely to be stronger in countries with high rates of internal mobility. The relatively high labour mobility may be responsible for the relatively benign impact of immigration on labour markets in the US (see Card, 2001). The evidence that internal migration is one of the mechanisms through which regional labour markets adjust to immigration shocks is likely to be much weaker. For example Hatton and Tani (2005) found effects for Britain that had the right negative sign (immigration leading to an outflow of natives) but were mostly statistically insignificant.

The estimates in Table 3 also suggest that a narrower definition of the labour market, for example, in terms of both areas and skills, yields a better identification of workers that are close substitutes to each other. This results in estimated effects of immigration that are around 0.1 points more negative than when the labour market is only defined in terms of geographical areas. Our previous meta-analysis on the effect of immigration on wages (Longhi et al., 2005) also found that immigration has a bigger impact on EU countries than on the US, and on more narrowly defined labour markets. These results are consistent with the idea that EU countries might not be more negatively affected by immigration than the US. Instead, the impact of immigration might be underestimated by those studies using US data.

Next, we also find that effect sizes focusing on women tend to estimate elasticities of employment to immigration that are between 0.03 and 0.04 points more negative than those estimated for men. This result is consistent with the higher elasticity of the women's labour force participation rate, and might suggest that women might be more affected than men by immigration. Longhi et al. (2005) found that wages of women are affected in the same way as wages of men. If immigrants are a closer substitute for women than for men, as suggested by Borjas (2003), the absence of any wage effect of immigration for female is consistent with its higher impact on female employment.

The significantly negative coefficients for estimating the effect by means of data on all workers workers, vis-à-vis low skilled workers is rather surprising. However, inspection of Table 2 shows that there were only 8 observations on low- 
skilled workers, compared with 157 observations for workers of all skills. It is possible that the regression estimates capture here some feature other than skills, or combination of features, that is responsible for this effect.

As expected, those studies correcting for endogeneity by means of instrumental variables approaches tend to lead to more negative estimates of elasticities of employment to immigration. This suggests that neglecting the opportunity of using instruments might underestimate the effects of the impact of immigration on employment.

Given the non-normal distribution of the effect sizes as displayed in Figure 1, we also carried out Jacknife and Bootstrap re-estimation of the OLS model of column (1). This has no effect on the regression coefficients, and only a small impact on the standard errors. The results are reported in columns (4) and (5). In most cases the level of statistical significance does not change and the results as discussed above are reinforced.

\section{Conclusions}

The impact of immigration on host societies continues to be a hotly debated topic, fuelled by racial tensions and large socio-economic disparities between areas with high concentrations of low skilled immigrants and more affluent areas. Recent research demonstrates that it is particularly those with low skills who perceive the greatest threat from immigration (e.g., Dustmann and Glitz 2005). It is in this context important to carry out a careful synthesis of the available empirical evidence. The present paper aimed to provide a quantitative synthesis with respect to one specific issue - the effect of immigration on employed of the native born - and using one particular type of empirical approach (the area approach).

The meta-analysis of 165 effect sizes shows that there is a statistically significant but almost negligibly small effect of immigration on native employment. The results complement those of the meta-analysis of the effect of immigration on wages of the native born reported in Longhi et al. (2005). Together these results reinforce the broad consensus among economists that in practice, when the labour market has adjusted in a number of ways, the impact of immigration is rather benign, even though ceteris paribus an immigration shock would lower wages and employment of the native born. 
Besides an assessment of the overall impact, the present meta-analysis has also revealed a number of interesting features in the cross-study comparison, such as the greater impact in Europe than in the US and the greater impact on women than on men, in addition to the importance of various study design features.

The present study can be extended in various ways. Firstly, it would be useful to obtain data on a wider range of studies, some of which may be available in unpublished form and some new studies which will undoubtedly become available over the next few years as the topic continues to attract interest. A much larger sample of studies would enable a clear comparison and explanation of the variation "within studies" as compared with "between studies".

Secondly, the present paper focussed on a single methodology only (the area approach) and it would be useful to compare results across a wider range of approaches. This will make it harder to measure effect sizes and may necessitate a more qualitative or ordinal assessment of the impact, such as has been done for example with logit/probit models and rough set analysis in the context of assessing the impact of government fiscal policy on economic growth by means of a large set of rather disparate empirical analyses (Nijkamp and Poot 2004).

There is certainly also scope for more primary studies, particularly for those that make a clear distinction between the short run and the long run effect. The longrun effect of immigration can of course span generations (see Card, 2005). Recent initiatives that have led to new longitudinal surveys of immigrants in a number of countries are also helpful for further research. Finally, it is clear that since the macro effects of immigration tends to be small and hard to detect, there is a need for further highly disaggregated studies using rich micro data sets of immigrants and the nativeborn.

\section{References}

Altonji, J.G. and Card, D. (1991). The Effect of Immigration on the Labor Market Outcomes of Less-Skilled Natives. Immigration, Trade and the Labor Market. Abowd, J.M. and Freeman, R.B., NBER: 201-234.

Angrist, J.D. and Kugler, A. (2003). Protective or Counter-Productive? Labor Market Institutions and the Effect of Immigration on Eu Natives. The Economic Journal 113: F302-F331. 
Ashenfelter, O., Harmon, C. and Oosterbeek, H. (1999). A Review of Estimates of the Schooling/Earnings Relationship, with Tests for Publication Bias. Labour Economics 6(4): 453-470.

Bhagwati, J. (ed.) (1976) The Brain Drain and Taxation: Theory and Empirical Analysis. Amsterdam: North Holland.

Borjas, G.J. (1996). Labor Economics. New York, McGraw Hill.

Borjas, G.J. (1999). The Economic Analysis of Immigration. Handbook of Labor Economics. Ashenfelter, O. and Card, D., North Holland. 3A: 1697-1760.

Borjas, G.J. (2003). The Labor Demand Curve Is Downward Sloping: Reexamining the Impact of Immigration on the Labor Market. Quarterly Journal of Economics 118(4): 1335-1374.

Borjas, G.J. (2005). Native Internal Migration and the Labor Market Impact of Immigration, NBER Working Paper No. 11610.

Borjas, G.J., Freeman, R.B. and Katz, L.F. (1997). How Much Do Immigration and Trade Affect Labor Market Outcomes? Brookings Papers on Economic Activity 1:1997: 1-90.

Card, D. (2001). Immigrant Inflows, Native Outflows, and the Local Market Impacts of Higher Immigration. Journal of Labor Economics 19(1): 22-64.

Card, D. (2005) Is the New Immigration Really so Bad? The Economic Journal 115: F300-F323.

Card, D. and Krueger, A.B. (1995). Time-Series Minimum-Wage Studies: A MetaAnalysis. The American Economic Review 85(2): 238-243.

Carrasco, R., Jimeno, J.F. and Ortega, A.C. (2004). The Effect of Immigration on the Employment Opportunities of Native-Born Workers: Some Evidence for Spain, Dept. of Economics Universidad Carlos III de Madrid Working Paper 04-61.

Cooper H. and Hedges L.V. (1994) The Handbook of Research Synthesis. New York: Russell Sage Foundation.

Dustmann, C., Fabbri, F. and Preston, I. (2005). The Impact of Immigration on the UK Labour Market, The Economic Journal 115: F324-341.

Dustmann, C. and Glitz, A. (2005) Immigration, Jobs and Wages: Theory, Evidence and Opinion. London: Centre for Economic Policy Research.

Enchautegui, M.E. (1997). Immigration and County Employment Growth. Population Research and Policy Review 16: 493-511.

Friedberg, R.M. (2001). The Impact of Mass Migration on the Israeli Labor Market. The Quarterly Journal of Economics 116(4): 1373-1408.

Friedberg, R.M. and Hunt, J. (1995). The Impact of Immigrants on Host Country Wages, Employment and Growth. The Journal of Economic Perspectives 9(2): 23-44.

Gorter, C., Nijkamp, P. and Poot, J. (1998) Crossing Borders: Regional and Urban Perspectives on International Migration. Aldershot UK: Ashgate.

Hatton, T.J. and Tani, M. (2005) Immigration and Inter-regional mobility in the UK, 1982-2000, The Economic Journal, 115: F342-F358.

Longhi, S., Nijkamp, P. and Poot, J. (2005). A Meta-Analytic Assessment of the Effect of Immigration on Wages. Journal of Economic Surveys 19(3): 451477.

Nijkamp, P. and Poot, J. (2004) Meta-Analysis of the Impact of Fiscal Policies on Long-Run Growth. European Journal of Political Economy, 20(1): 91-124 
Okkerse, L. (2005) The Impact of Immigrants on the Labour Market. In: H. de Smet et al. (eds.) Unexpected Approaches to the Global Society. Antwerpen: Garant, 37-59.

Pischke, J.-S. and Velling, J. (1997). Employment Effects of Immigration to Germany: An Analysis Based on Local Labor Markets. the review of Economics and Statistics 79: 594-604.

Poot, J. and Cochrane, B. (2005) Measuring the Economic Impact of Immigration: a Scoping Paper, Discussion Ppaer No. 48, Population Studies Centre, University of Waikato.

Roberts, C.J. (2005) Issues in Meta-Regression Analysis: An Overview, Journal of Economic Surveys 19(3): 295-298.

Stanley, T.D., Florax, R.J.G.M. and de Groot, H.L.F. (2004). It's All About Power: Differentiating Genuine Empirical Significance from the Artifact of Publication Bias, Mimeo.

Sutton, A.J., Abrams, K.R., Jones, D.R., Sheldon, T.A. and Song, F. (2000). Methods for Meta-Analysis in Medical Research. New York, John Wiley and Sons.

Winter-Ebmer, R. and Zimmermann, K.F. (1998). East-West Trade and Migration: The Austro-German Case. Bonn, IZA Discussion Paper No. 2. 


\section{Tables and Figures}

Table 1. Primary studies estimating the impact of immigration on local employment

\begin{tabular}{clcc}
\hline Id. No. & \multicolumn{1}{c}{ Reference } & Country & $\begin{array}{c}\text { No. of } \\
\text { Effect Sizes }\end{array}$ \\
\hline 1 & Borjas et al. (1997) & US & 14 \\
2 & Enchautegui (1997) & US & 6 \\
3 & Pischke and Velling (1997) & West Germany & 12 \\
4 & Winter-Ebmer and Zimmermann (1998) & Austria; West Germany & 16 \\
5 & Card (2001) & US & 28 \\
6 & Friedberg (2001) & Israel & 2 \\
7 & Angrist and Kugler (2003) & EU & 48 \\
8 & Carrasco et al. (2004) & Spain & 33 \\
9 & Dustmann et al. (2005) & UK & 6 \\
\hline & Total & & $\mathbf{1 6 5}$ \\
\hline
\end{tabular}

Table 2. Descriptive Statistics

\begin{tabular}{|c|c|c|c|c|c|c|}
\hline Group & Moderator Variable & No. & Mean & St. Dev. & Min & $\operatorname{Max}$ \\
\hline All Elasticities & & 165 & -0.024 & 0.116 & -0.390 & 0.620 \\
\hline \multirow[t]{2}{*}{ Country } & Other Countries & 117 & -0.032 & 0.114 & -0.390 & 0.477 \\
\hline & $\mathrm{US}^{(\#)}$ & 48 & -0.005 & 0.121 & -0.202 & 0.620 \\
\hline \multirow[t]{2}{*}{ Size of the Area } & Big & 111 & -0.033 & 0.115 & -0.390 & 0.477 \\
\hline & Small $^{(\#)}$ & 54 & -0.006 & 0.117 & -0.202 & 0.620 \\
\hline \multirow[t]{2}{*}{ Definition of Local Labour Market } & Areas and Skills & 75 & -0.040 & 0.091 & -0.390 & 0.477 \\
\hline & Areas ${ }^{(\#)}$ & 90 & -0.011 & 0.133 & -0.301 & 0.620 \\
\hline \multirow[t]{3}{*}{ Gender } & Both Genders & 57 & 0.011 & 0.154 & -0.203 & 0.620 \\
\hline & Women & 54 & -0.050 & 0.114 & -0.390 & 0.477 \\
\hline & $\operatorname{Men}^{(\#)}$ & 54 & -0.034 & 0.042 & -0.202 & 0.018 \\
\hline \multirow[t]{2}{*}{ Native' Skills } & All Skills & 157 & -0.023 & 0.119 & -0.390 & 0.620 \\
\hline & Low Skills ${ }^{(\#)}$ & 8 & -0.041 & 0.017 & -0.068 & -0.020 \\
\hline \multirow[t]{3}{*}{ Focus } & No Distinction & 40 & -0.035 & 0.096 & -0.301 & 0.351 \\
\hline & Earlier Immigrants & 14 & -0.047 & 0.037 & -0.146 & -0.007 \\
\hline & Natives ${ }^{(\#)}$ & 111 & -0.017 & 0.129 & -0.390 & 0.620 \\
\hline \multirow[t]{2}{*}{ Data } & Cross-Section & 114 & -0.044 & 0.095 & -0.390 & 0.477 \\
\hline & First Differences ${ }^{(\#)}$ & 51 & 0.021 & 0.144 & -0.183 & 0.620 \\
\hline \multirow[t]{2}{*}{ Weights } & No & 122 & -0.023 & 0.110 & -0.390 & 0.620 \\
\hline & Yes ${ }^{(\#)}$ & 43 & -0.026 & 0.133 & -0.202 & 0.470 \\
\hline \multirow[t]{2}{*}{ Instruments } & No & 104 & -0.012 & 0.109 & -0.390 & 0.620 \\
\hline & Yes $^{(\#)}$ & 61 & -0.044 & 0.127 & -0.301 & 0.470 \\
\hline
\end{tabular}

(\#) Used as reference category in the meta-regressions 
Table 3. Meta-Regression Analysis

\begin{tabular}{|c|c|c|c|c|c|c|}
\hline Group & Study Characteristics & $\begin{array}{c}(1) \\
\text { OLS }\end{array}$ & $\begin{array}{c}(2) \\
\text { WLS }\end{array}$ & $\begin{array}{l}\text { (3) } \\
\text { ML }\end{array}$ & $\begin{array}{c}\text { (4) } \\
\text { Jacknife }\end{array}$ & $\begin{array}{c}(5) \\
\text { Bootstrap }\end{array}$ \\
\hline \multirow[t]{2}{*}{ Country } & Other Countries & $\begin{array}{r}-0.1083^{* *} \\
(0.0420)\end{array}$ & $\begin{array}{r}-0.0870^{* *} \\
(0.0415)\end{array}$ & $\begin{array}{r}-0.1137 * * * \\
(0.0334)\end{array}$ & $\begin{array}{r}-0.1083^{* *} \\
(0.0451)\end{array}$ & $\begin{array}{r}-0.1083 * * \\
(0.0456)\end{array}$ \\
\hline & US & & & & & \\
\hline \multirow[t]{2}{*}{ Size of the Area } & Big & $\begin{array}{r}0.0169 \\
(0.0199)\end{array}$ & $\begin{array}{r}0.0008 \\
(0.0365)\end{array}$ & $\begin{array}{r}0.0122 \\
(0.0269)\end{array}$ & $\begin{array}{r}0.0169 \\
(0.0211)\end{array}$ & $\begin{array}{r}0.0169 \\
(0.0206)\end{array}$ \\
\hline & Small & - & - & - & - & - \\
\hline \multirow[t]{2}{*}{ Definition of Local Labour Market } & Areas and Skills & $\begin{array}{r}-0.0951 * * * \\
(0.0289)\end{array}$ & $\begin{array}{r}-0.1050 * * * \\
(0.0269)\end{array}$ & $\begin{array}{r}-0.0982 * * * \\
(0.0244)\end{array}$ & $\begin{array}{r}-0.0951^{* * *} \\
(0.0308)\end{array}$ & $\begin{array}{r}-0.0951^{* * *} * \\
(0.0302)\end{array}$ \\
\hline & Only Areas & - & - & - & - & - \\
\hline \multirow[t]{3}{*}{ Gender } & Both Genders & $\begin{array}{r}0.0154 \\
(0.0278)\end{array}$ & $\begin{array}{r}-0.0079 \\
(0.0223)\end{array}$ & $\begin{array}{r}0.0145 \\
(0.0260)\end{array}$ & $\begin{array}{r}0.0154 \\
(0.0301)\end{array}$ & $\begin{array}{r}0.0154 \\
(0.0295)\end{array}$ \\
\hline & Women & $\begin{array}{r}-0.0420 * * * \\
(0.0135)\end{array}$ & $\begin{array}{r}-0.0308 \\
(0.0204)\end{array}$ & $\begin{array}{r}-0.0398 * * \\
(0.0200)\end{array}$ & $\begin{array}{r}-0.0420 * * * \\
(0.0139)\end{array}$ & $\begin{array}{r}-0.0420 * * * \\
(0.0150)\end{array}$ \\
\hline & Men & - & - & - & - & - \\
\hline \multirow[t]{2}{*}{ Native' Skills } & All Skills & $\begin{array}{r}-0.0683 * * * \\
(0.0214)\end{array}$ & $\begin{array}{r}-0.0885 * * \\
(0.0358)\end{array}$ & $\begin{array}{c}-0.0740 * \\
(0.0400)\end{array}$ & $\begin{array}{r}-0.0683 * * * \\
(0.0233)\end{array}$ & $\begin{array}{r}-0.0683 * * * \\
(0.0227)\end{array}$ \\
\hline & Low Skills & - & - & - & - & - \\
\hline \multirow[t]{3}{*}{ Focus } & No Distinction & $\begin{array}{r}-0.0278 \\
(0.0211)\end{array}$ & $\begin{array}{r}-0.0313 \\
(0.0344)\end{array}$ & $\begin{array}{r}-0.0219 \\
(0.0252)\end{array}$ & $\begin{array}{r}-0.0278 \\
(0.0223)\end{array}$ & $\begin{array}{r}-0.0278 \\
(0.0211)\end{array}$ \\
\hline & Earlier Immigrants & $\begin{array}{r}0.0041 \\
(0.0190)\end{array}$ & $\begin{array}{r}0.0036 \\
(0.0301)\end{array}$ & $\begin{array}{r}0.0057 \\
(0.0342)\end{array}$ & $\begin{array}{r}0.0041 \\
(0.0207)\end{array}$ & $\begin{array}{r}0.0041 \\
(0.0210)\end{array}$ \\
\hline & Natives & - & - & - & - & - \\
\hline \multirow[t]{2}{*}{ Data } & Cross-Section & $\begin{array}{r}-0.0312 \\
(0.0191)\end{array}$ & $\begin{array}{c}-0.0502 * \\
(0.0286)\end{array}$ & $\begin{array}{r}-0.0356 \\
(0.0237)\end{array}$ & $\begin{array}{r}-0.0312 \\
(0.0206)\end{array}$ & $\begin{array}{r}-0.0312 \\
(0.0210)\end{array}$ \\
\hline & First Differences & - & - & - & - & - \\
\hline \multirow[t]{2}{*}{ Weights } & No & $\begin{array}{r}0.0115 \\
(0.0241)\end{array}$ & $\begin{array}{r}0.0140 \\
(0.0328)\end{array}$ & $\begin{array}{r}0.0206 \\
(0.0275)\end{array}$ & $\begin{array}{r}0.0115 \\
(0.0253)\end{array}$ & $\begin{array}{r}0.0115 \\
(0.0256)\end{array}$ \\
\hline & Yes & - & - & - & - & - \\
\hline
\end{tabular}




\begin{tabular}{|c|c|c|c|c|c|c|}
\hline Instruments & No & $\begin{array}{r}0.0892 * * * \\
(0.0206)\end{array}$ & $\begin{array}{r}0.1084 * * * \\
(0.0273)\end{array}$ & $\begin{array}{r}0.0920 * * * \\
(0.0227)\end{array}$ & $\begin{array}{r}0.0892 * * * \\
(0.0221)\end{array}$ & $\begin{array}{r}0.0892 * * * \\
(0.0214)\end{array}$ \\
\hline & Yes & & & & & \\
\hline Publication Bias & Standard Error of the Effect Size & $\begin{array}{r}1.0729 * * * \\
(0.3805)\end{array}$ & $\begin{array}{r}0.7470 * * * \\
(0.1832)\end{array}$ & $\begin{array}{r}0.8963 * * * \\
(0.1951)\end{array}$ & $\begin{array}{r}1.0729 * * \\
(0.4384)\end{array}$ & $\begin{array}{r}1.0729 * * \\
(0.5034)\end{array}$ \\
\hline Constant & & $\begin{array}{r}0.0868 * * * \\
(0.0327)\end{array}$ & $\begin{array}{r}0.1157 * * * * \\
(0.0439)\end{array}$ & $\begin{array}{r}0.0953^{* *} \\
(0.0451)\end{array}$ & $\begin{array}{r}0.0868 * * \\
(0.0345)\end{array}$ & $\begin{array}{r}0.0868 \text { *** } \\
(0.0339)\end{array}$ \\
\hline $\mathrm{Nr}$ of Observations & & 165 & 165 & 165 & 165 & 165 \\
\hline Correlation between Observed and & Fitted Effect Size & 0.5871 & 0.4958 & 0.5791 & 0.5871 & 0.5871 \\
\hline Adjusted $\mathrm{R}^{2}$ & & 0.2929 & 0.3215 & - & 0.2929 & 0.2929 \\
\hline
\end{tabular}

Standard errors in parenthesis; * Significant at 10\%, ** Significant at 5\%, *** Significant at 1\% 


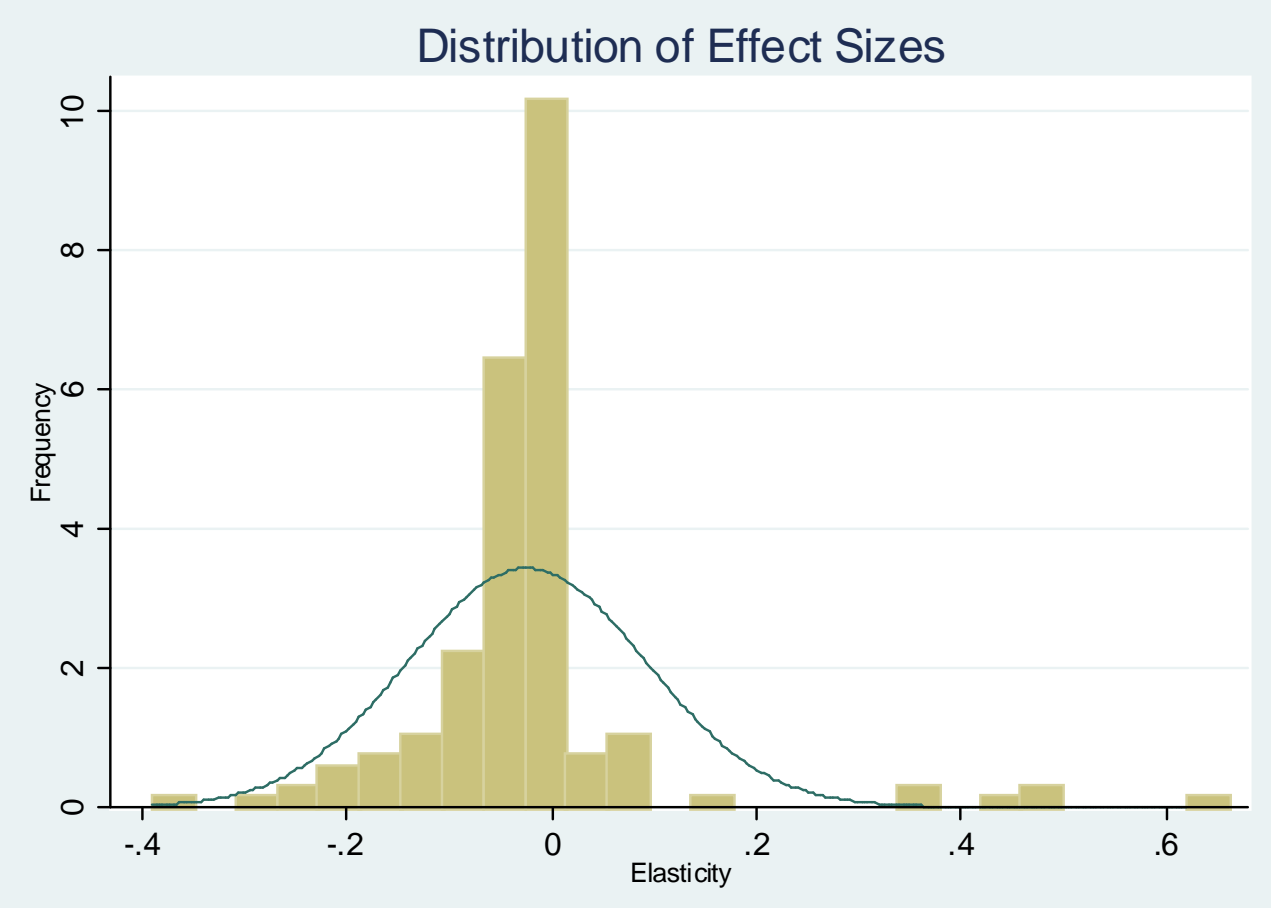

Fig. 1. Distribution of the effect sizes

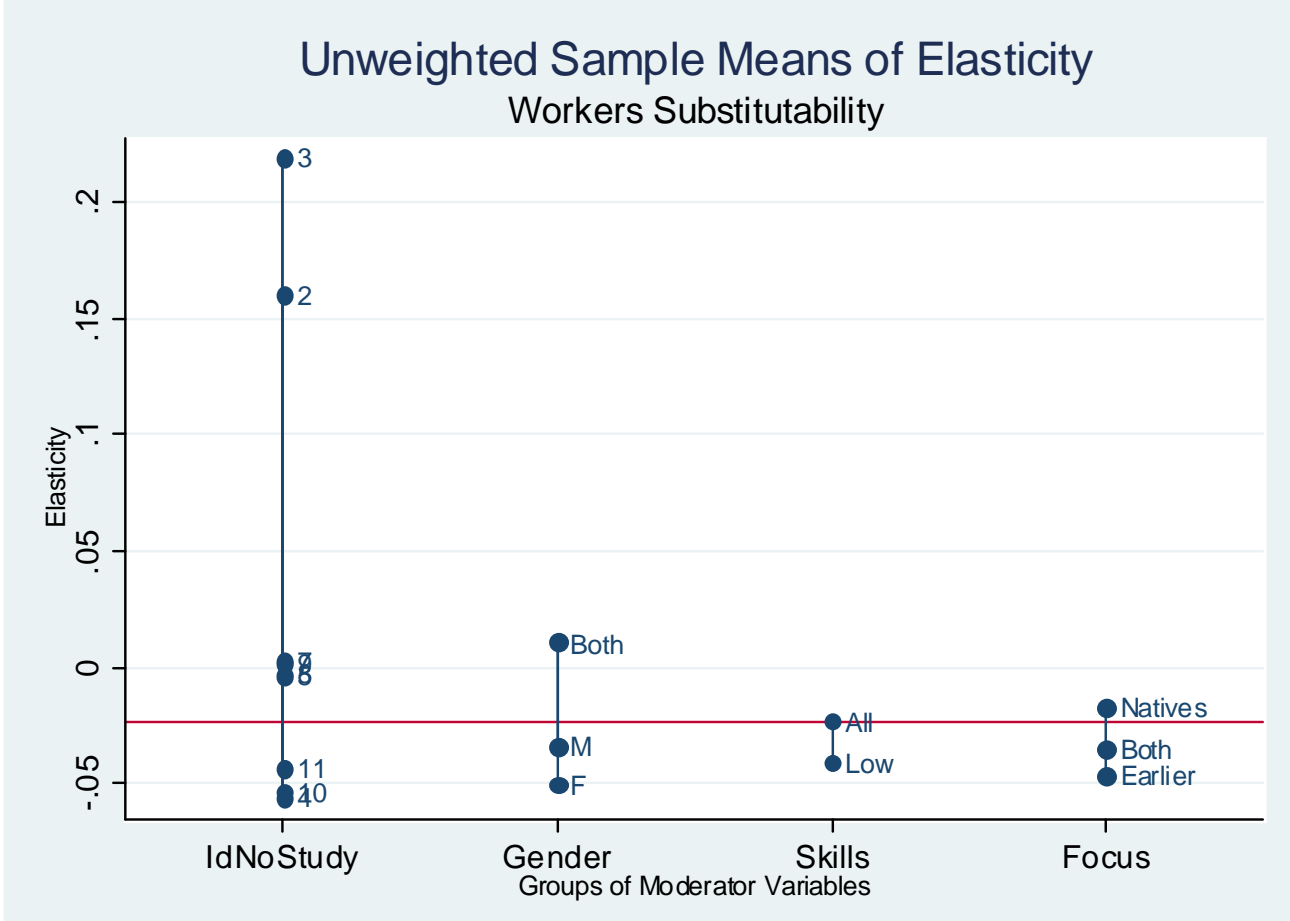

Fig. 2. Univariate means by groups (workers substitutability) 


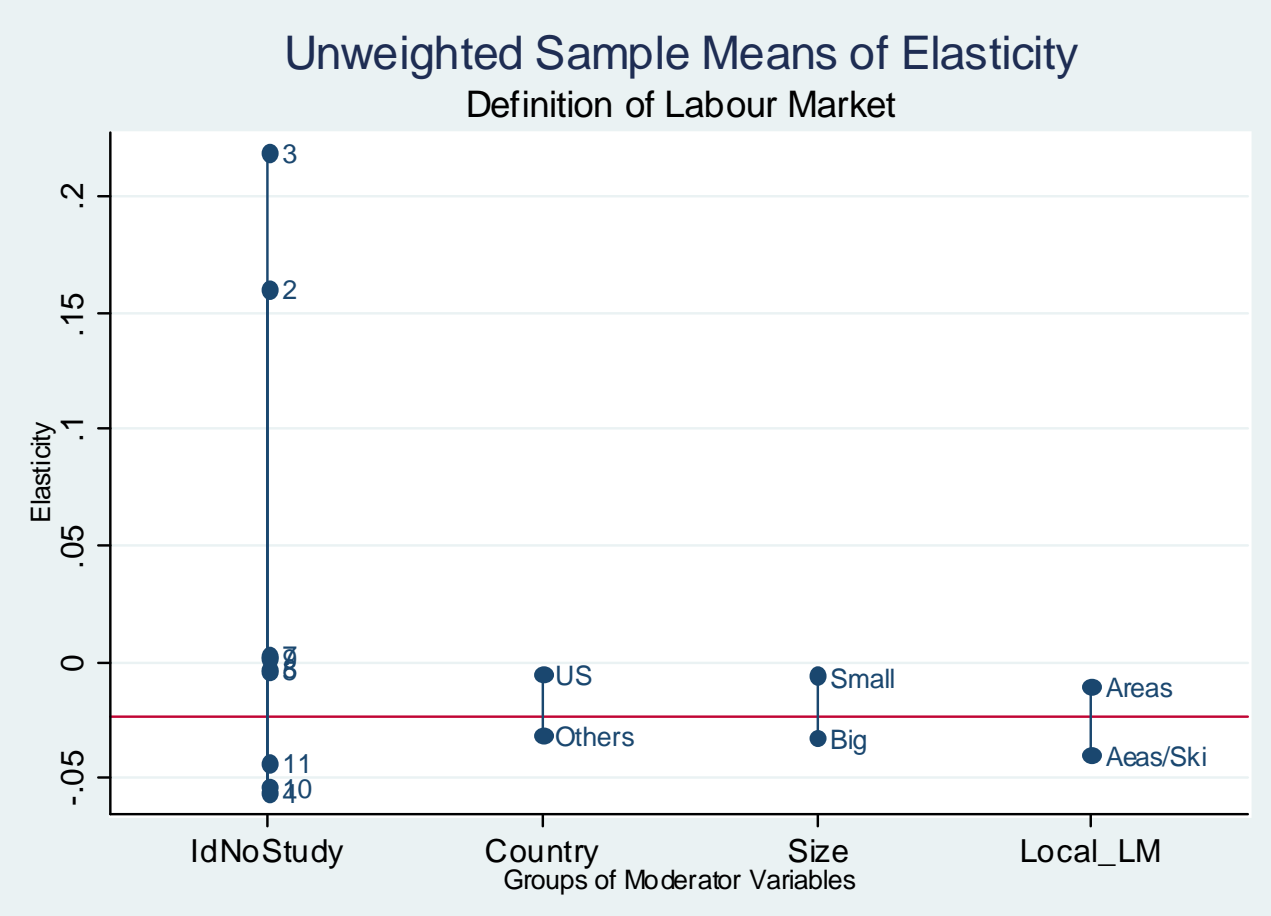

Fig. 3. Univariate means by groups (definitions of the labour market)

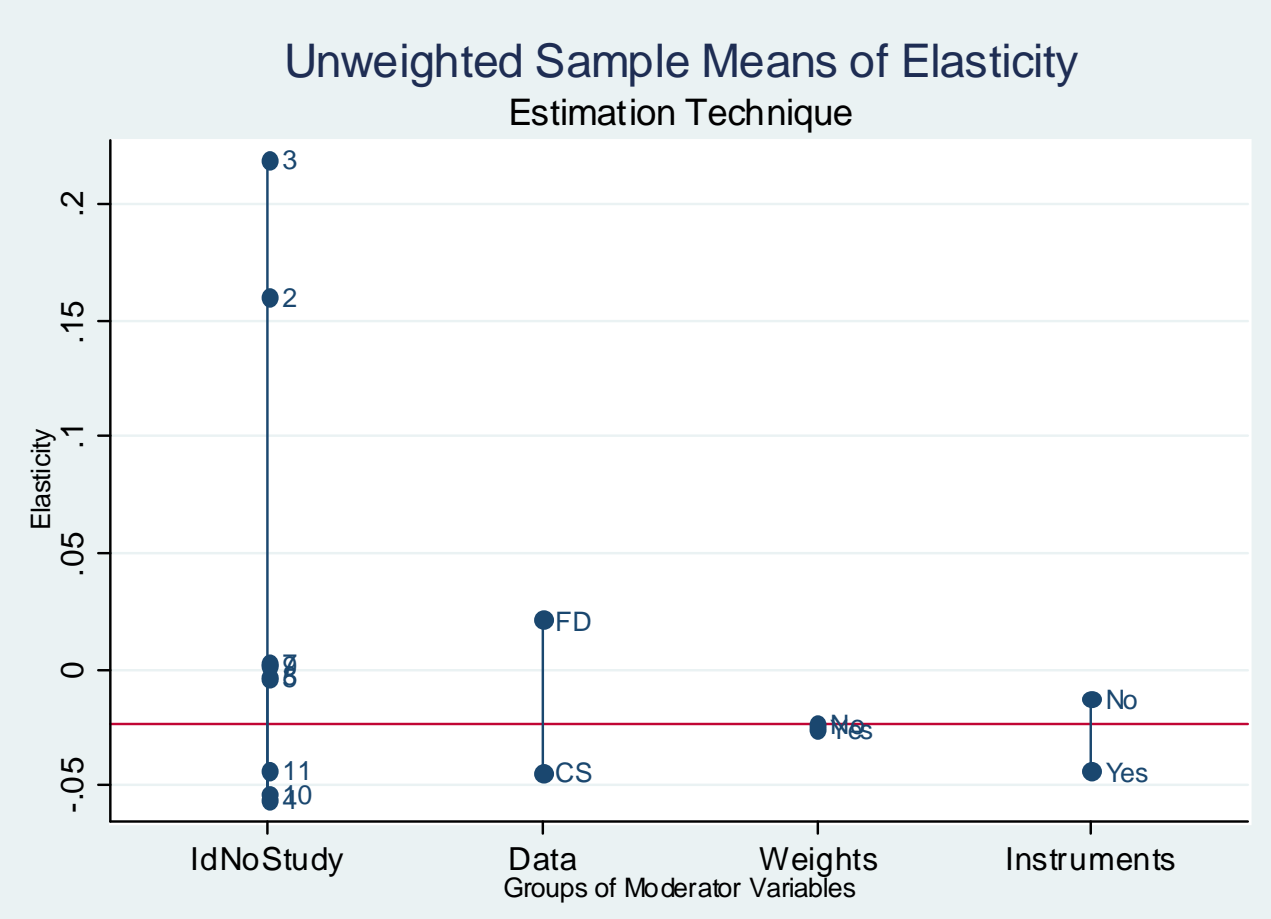

Fig. 4. Univariate means by groups (estimation technique) 